\title{
Isotopic Composition of Aerosol Nitrate in the Pacific Atmosphere
}

\author{
M.G. HASTINGS1, E. JOYCE1, T. CARTER2
}

1Brown University, Providence, RI, 02912, USA

1Massachuetts Institute of Technology, Cambridge, MA, 02139, USA

(*correspondence: meredith_hastings@brown.edu)

Atmospheric nitrate (NO3-) makes up a major portion of atmospheric deposition (AD) in the Pacific (i.e., precipitation and aerosols), and is the primary sink of nitrogen oxides ( $\mathrm{NO}_{\mathrm{x}}$ $=\mathrm{NO}+\mathrm{NO}_{2}$ ) from the atmosphere. $\mathrm{AD}$ could be an important $\mathrm{N}$ source for the North Pacific. For example, only $\sim 1.5$ of the 2 mol C m-2y-1 measured at Station ALOHA $\left(22.75^{\circ} \mathrm{N}\right.$, $\left.158.00^{\circ} \mathrm{W}\right)$ can be accounted for via $\mathrm{N}_{2}$ fixation and mesoscale mixing. Additionally, cruise-based data in the North Pacific show an excess of $\mathrm{N}$ in the last few decades that has been suggested to be the result of increased $\mathrm{AD}$ from emissions in Asia. We quantified the concentrations and stable isotopes of $\mathrm{NO}_{3-}\left(\delta_{15 \mathrm{~N}-}, \delta_{18} \mathrm{O}-, \Delta_{17} \mathrm{O}_{-} \mathrm{NO}_{3}\right)$ in aerosols collected during two GEOTRACES cruises: 1) Alaska to Tahiti in 2018 (GP15; 55.0 to $-20.0^{\circ} \mathrm{N}, 152.0^{\circ} \mathrm{W}$ ), and 2) Peru to Tahiti in $2013\left(\mathrm{GP} 16 ; 4.1^{\circ} \mathrm{S}, 81.9^{\circ} \mathrm{W}\right.$ to $\left.10.5^{\circ} \mathrm{S}, 152.0^{\circ} \mathrm{W}\right)$. The $\delta_{15} \mathrm{~N}-\mathrm{NO}_{3}$ - ranges from -1.1 to $-13.1 \%$, with the lowest values occuring in the Equatorial Pacific, and away from the coasts, reflecting a combination of $\mathrm{NO}_{\mathrm{x}}$ sources, transport and chemistry. The majority $(75 \%)$ of $\mathrm{NO}_{\mathrm{x}}$ in the atmosphere is derived from anthropogenic sources (e.g., fossil fuel combustion), with the remaining $\sim 25 \%$ from natural sources (e.g., lightning). The ocean is not a direct source of $\mathrm{NO}_{\mathrm{x}}$; however, photolysis of alkyl nitrates $\left(\mathrm{RONO}_{2}\right)$ emitted from the ocean can alter the $\mathrm{NO}$ budget. The $\delta_{18} \mathrm{O}$ - and $\Delta_{17} \mathrm{O}-\mathrm{NO}_{3}$ both show a decreasing trend from Alaska to Tahiti, as well as moving away from the coast of Peru, reflecting a change in the major oxidant chemistry. The $\delta_{18} \mathrm{O}$ and $\Delta_{17} \mathrm{O}$ of atmospheric $\mathrm{NO}_{3}$ - are high $(65.2-85.4 \%$ and $21.4-30.7 \%$, respectively) reflecting the isotopic influence of ozone oxidation on $\mathrm{NO}_{x}$. Both $\delta 18 \mathrm{O}$ and $\Delta_{17} \mathrm{O}$ decrease with increasing distance from high $\left[\mathrm{NO}_{\mathrm{x}}\right]$ regions (i.e. continental), likely reflecting a decrease in atmospheric ozone concentrations. These lower values may also be associated with the influence of $\mathrm{RONO}_{2}$ on $\mathrm{NO}_{3}$ - production in the region, because the $\delta 15 \mathrm{~N}-, \delta_{18} \mathrm{O}-$ and $\Delta_{17} \mathrm{O}-\mathrm{RONO}_{2}$ are expected to be low. This information betters our collective understanding of the oxidative capacity and atmospheric chemistry over the Pacific. The very low $\delta_{15} \mathrm{~N}_{-} \mathrm{NO}_{3}-$ throughout the Pacific atmosphere represents an isotopically light source of $\mathrm{N}$ to the surface ocean, and the uniquely high oxygen isotopic compostion could serve as a tracer of unclyced $\mathrm{NO}_{3}$-. 